\title{
REGULATING THE RELATIONSHIP BETWEEN STATE AND RELIGION: AN ECONOMIC APPROACH
}

\author{
Ann-Sophie Vandenberghe*
}

\begin{abstract}
In defining its relationship towards religion, the Dutch government is committed to the values of freedom of religion and neutrality. This article uses the economic approach to freedom of religion and state neutrality as a tool for looking at the existing Dutch policy of state aid to religion and at the Dutch freedom of religion cases. This investigation shows that the Dutch outcomes in religious cases follow a pattern of economic neutrality to a large extent, but that there are also deviations. This is especially the case for the policy of the Dutch (local) government to grant benefits to religious organisations based on a belief that the promotion of religion will provide positive results for society. Can religion contribute much to the enforcement of moral and social norms under conditions of modernity? This article seeks to contribute to this discussion by adding the insights of the economic literature on the enforcement of moral and social norms.
\end{abstract}

Keywords: Social norms; religious freedom; neutrality

\section{Introduction}

During the past few years, much attention has been paid to legal cases involving the relationship between religion and the state. May civil servants refuse, on religious grounds, to conclude gay marriages? May a city deny welfare benefits to a person who refuses on religious grounds to accept a job involving the sale of lottery tickets? ${ }^{1}$ Should religious symbols, such as a crucifix, be removed from public schools? ${ }^{2}$ May religion be exempted from secularly motivated laws of general applicability, such as the law on identification $^{3}$ and the opium law? ${ }^{4}$

The outcomes of these cases depend on the values that courts and legislators pursue in society. Dutch courts and legislators are constitutionally committed to the value of freedom of religion (Article 6 Dutch Constitution). Freedom of religion or free exercise claims are commonly directed towards government regulations, which distort a person's free exercise or expression of religion. Such claims commonly concern laws or regulations of general applicability that are especially burdensome for religion. Plaintiffs then ask, and sometimes obtain, an exception based on religious grounds from the law of general applicability. While the Dutch government is not free to burden religion, the other side of the coin is that the Dutch government is not free to provide particular benefits to religion in general (or to particular faiths). The Dutch state is restricted to give particular benefits to religion on the basis of the principle of the separation between church and state.

It is sometimes said that there is a 'tension' between the right to freedom of religion, on the one hand, and the separation between church and state, on the other hand. And that what is required under freedom of religion (the exceptions granted to religion from laws of general applicability) are benefits to religion prohibited by the principle of separation of church and state (state promotion of religions is prohibited). It is also argued that what is forbidden under the separation of church and state is a burden on religion against which freedom of religion offers protection. However, this tension arises only with an overzealous interpretation of freedom of religion or a too strict approach of the principle

\footnotetext{
Assistant Professor, Erasmus School of Law, Rotterdam Institute of Law and Economics.

District Court Amsterdam, 24 May 2007, LJN: BA6917.

Lautsi and others v. Italy, ECHR (18 March 2011).

District Court The Hague, 17 February 2012. http:/www.rechtspraak.nl/Organisatie/Rechtbanken/ Den-Haag/Nieuws/Pages/Uitspraak-kantonrechter-in-zaak-over-identificatieplicht.aspx.

4 Court of Appeal Amsterdam, 24 February 2012, LJN: BV6888.
} 
of separation. If 'benefits and burdens' on religion are correctly understood, there is no longer a tension. Because the Dutch government is also committed to the principle of neutrality, the real question in assessing benefits and burdens on religion is whether state action (or non-action) is neutral in its impact on religion. For example, the Dutch government provides publicly funded subsidies to religious schools. Strictly speaking, this is a benefit given to religious organisations. But is this state action neutral in its impact on religion? Or alternatively, would a denial of public subsidies to religious schools be neutral? What is the proper reference point for determining whether a denial of benefits, or alternatively, a grant of benefits, is neutral in its impact on religion?

McConnell and Posner have developed an economic approach to issues of religious freedom and neutrality. ${ }^{5}$ This article uses this economic approach to freedom of religion and state neutrality as a tool for looking at the existing Dutch pattern for state aid to religion and at the legal outcomes in Dutch freedom of religion cases with a view to determining whether they follow the logic of the economic approach. The article proceeds as follows:

Section 2 sets out the basic economic approach of freedom of religion and neutrality. A country's commitment to freedom of religion and neutrality is taken for granted. Economics cannot say what values should be pursued in society, but it can say something from an economic point of view about how a given goal, such as freedom of religion, can best be achieved. The economic approach to religious choice takes the model of the free market for religious belief as its benchmark. Section 3 deals with the issue of publicly funded subsidies to religion. Should these subsidies be permitted from a purely economic point of view of neutrality (Section 3.1)? Does the existing Dutch policy of state aid to religious organisations follow the logic of economic neutrality (Section 3.2)? Section 4 looks at religious exemptions from laws and regulations of general applicability. Section 4.1 sets out the economic framework for solving claims based on freedom of religion. In Section 4.2 this economic framework is used to re-examine the legal outcomes of some Dutch freedom of religion cases.

The Dutch policy in religious cases largely follows a pattern of economic neutrality, but not always. A deviation exists, for example, in the case of the policy of (local) government to provide benefits to religious organisations based on a belief that the promotion of religion produces positive results for society. ${ }^{6}$ Some argue that modern societies may be ripe for a moral revolution and that religion plays a vital role in this process. For example, the current English Prime Minister, David Cameron, has said that the United Kingdom is experiencing a slow-motion moral collapse and that religion must help to offer solutions. ${ }^{7}$ But can religion contribute a great deal to the enforcement of social and moral norms under the conditions prevailing in a modern society? This question is addressed in Section 5 by using the economic analysis of the enforcement of social and moral norms.

\section{An Economic Approach to Freedom of Religion and Neutrality}

\subsection{An Economic Approach to Freedom of Religion}

The Netherlands is committed to the value of 'freedom of religion'. Article 6 of the Dutch Constitution states that everyone shall have the right to manifest freely his religion or belief, either individually or in community with others, without prejudice to his responsibility under the law. Article 9 of the European Convention of Human Rights provides a right to freedom of thought, conscience and religion. This includes the freedom to change a religion or belief and to manifest a religion or belief in worship,

\footnotetext{
M.W. McConnell and R.A. Posner, 'An Economic Approach to Issues of Religious Freedom', 56 University of Chicago Law Review 1 (1989).

For example, the 2008 Amsterdam Note on the Separation of Church and State (Notitie Scheiding Kerk en Staat, 2008).

Speech given by David Cameron on 16 December 2011, see <http://www.winnipegfreepress. $\mathrm{com} /$ fpnewstopstory/britains-cameron-after-riots-religion-has-role-to-play-in-halting-uks-moralcollapse-135743573.html>.
} 
teaching, practice and observance, subject to certain restrictions that are 'in accordance with law' and 'necessary in a democratic society'. How can the value of freedom of religion best be achieved from an economic perspective?

Constitutions or treaties providing for the right to freedom of religion can be understood as positing that the 'market' - the realm of private choice - will reach the 'best' religious results, or more accurately, that the government has no authority to alter such results. Accordingly, freedom of religion can be understood in economic terms as a constitutionally prescribed free market for religious belief. ${ }^{8}$ The creation of a free market requires the protection of religious choice from government interference whether in favour of a religion (or religion in general) or against it. This can best be achieved by requiring that the government takes a neutral stance towards religion. State action or non-action is neutral in an economic sense if it creates neither incentives nor disincentives to engage in religious activities, thereby effectively creating a free market of religion.

\subsection{The Free Market for Religious Belief}

In the economic analysis of the free market model for religious belief, religious organisations are seen as firms providing services to consumers of religious services. ${ }^{9}$ Religious institutions provide many services: instruction about universal and transcendental truths; opportunities for ritual and worship; guidance about how to lead an ethical and satisfying life; care for the poor, the sick, the orphaned and the alien; facilities for promoting fellowship and a sense of community; and education. Religious organisations need money, donated time and services, and members for their activities. For this reason, they compete among themselves as well as with non-religious providers of substitute services, such as public and private secular providers. Competing religious organisations are able to attract new adherents and to keep existing ones by satisfying people's preferences. At the heart of any economic theory of religion is the notion of religion as a commodity, an object of choice. ${ }^{10}$ Consumers choose what religion (if any) they will accept and how extensively they will participate in it. These choices are not immutable - people can and often do change religions or levels of participation over time. Religious mobility in a religious competitive market can take many forms. It consists of (1) people leaving their faith or entering a particular faith, (2) people who change denominations, (3) internal mobility between different branches of a particular faith and (4) members who disaffiliate temporarily, ceasing to practise their religion for a certain period. As with any other commodity, the consumer's freedom to choose constrains the producers of religion. A particular religious firm can flourish only if it provides a commodity that is at least as attractive as its competitors. Competition provides opportunities for new religious belief systems, including atheistic beliefs, to cater better to people's desires. Competition among religions allows for entry of producers, including new religious ideologies that cater better to the preferences and needs of people, be they spiritual needs or materialistic ones. Can new religions effectively enter the religious market? From an economic point of view, they can easily enter because the capital requirements and start-up costs for new religions are virtually nil. ${ }^{11}$

The model of the free and competitive market for religious belief is useful for making predictions about the likely effects of government action. Economic analysis indicates that the effect of governmental action is far more ambivalent than popular opinion suggests. An interesting economic insight is that a state-supported church may in fact reduce participation in its religious activities. Although atheists are in the forefront

\footnotetext{
McConnell and Posner, above n. 5, at 60.

The foundation for an economic theory of religious institutions was laid by Adam Smith more than 200 years ago (A. Smith, An Inquiry into the Nature and Causes of The Wealth of Nations, edited by R.H. Campbell, A.S. Skinner and W.B. Todd [1776/1976]).

10 L.R. Iannaccone, 'The Consequences of Religious Market Structure: Adam Smith and the Economics of Religion', 3 Rationality and Society 156, at 158 (1991).

11 Iannaccone, above n. 10, at 159.
} 
of litigation against alleged establishments of religion, there is a powerful argument, first made by David Hume, that an established church weakens rather than strengthens religious belief. ${ }^{12}$ Hume thought that religious officials paid by government would act like other civil servants. They would have no pecuniary incentive to make converts or maximise church attendance; if you are paid a salary that is independent of your output, you will not be motivated beyond the minimum requirement of the job. State support creates a lazy monopolist. More generally, the creation of church monopoly power through government licensing, or the establishment of a state religion, would diminish a religious seller's effort to meet consumer tastes. Over time, the clergy of a state-supported church would become distant from the concerns of the church members. The consumer turns to non-religious substitutes. A competitive market in religion, on the other hand, would allow new churches to continually enter in order to meet the needs of consumers. The threat of new churches would force established churches to remain in touch with the desires of their members and to charge competitive prices for religious services. Moreover, when the competitive playing field is equal there will be more religious variety. The consumer of religious services has more choices and is therefore more likely to find a religious faith that suits him. A reduction in religious variety, on the other hand, will reduce demand for religious services, because the consumer of religious services has more difficulty in finding a religious faith that suits him. There are, however, offsetting considerations for the claim that state sponsorship of religion decreases a nation's religiosity by reducing religious variety: (1) The subsidy may stimulate demand for the established church by reducing the quality-adjusted cost of attending it - suppose the subsidy is used to build magnificent cathedrals or hire outstanding organists and choirs. The increased demand for the services of the established church may offset the lack of religious variety, (2) An established church might, by reducing religious diversity, quell the religious doubts that such diversity promotes. Many religions have striven to create a monopoly of belief, since religious diversity may create skepticism.

Iannaccone finds empirical support for the claim that an established church reduces participation in religious activities. ${ }^{13}$ Among Protestants, at least, both church attendance and religious belief are higher in countries with numerous competing churches than in countries dominated by a single church. It can also be observed that in the United States where there is no established church and more competition among religions, there is an increase in religious activity. In some Western-European countries that have established churches, religiosity has diminished. But there are counterexamples. In Poland and Ireland, which actively support a particular religion, religion has not diminished.

\subsection{An Economic Approach to Neutrality}

The relationship between church and state in the Netherlands is governed by the principle of neutrality. According to this principle, commonly understood, the government may not advantage a particular religion. The principle that government must take a neutral stance towards religion can be understood in economic terms as (1) the prohibition of public subsidies of either religion in general or, a fortiori, particular religious sects and (2) the prohibition for government to single out religion (or, again, particular sects) for taxation. Why should a state be neutral towards religion? From an economic perspective, the goal of freedom of religion, understood as the creation of a free market for religious belief, is best achieved by requiring that the state takes a neutral stance towards religion. ${ }^{14}$

\footnotetext{
See for reference to David Hume on this point, G.M. Anderson, 'Mr. Smith and the Preachers: The Economics of Religion in the Wealth of Nations', 96 Journal of Political Economy 1066, at 1073 (1988).

13 Iannaccone, above n. 10.

14 McConnell and Posner, above n. 5, at 60.
} 
The use of a free-market benchmark is important because it identifies ways in which government policy distorts (sometimes unintentionally) the pattern of economic activities, causing resources to flow from higher-valued uses to lower-valued uses. According to McConnell and Posner:

Because religious organizations need money (as well as donated time and services) for their activities, the scope of those activities will be influenced by governmental actions that have the effect of either taxing or subsidizing religion generally or particular religious organizations. Religious believers, moreover, are not insensitive to considerations of cost. So if the state, whether through pecuniary or nonpecuniary exactions, makes it more costly to adhere to one creed than to another (including the creed of nonbelief), this may cause a shift in religious affiliations. ${ }^{15}$

Compared with the free-market benchmark, governmental actions that have the effect of subsidisation of religious activity will normally expand the regulated activity, and when the action has the effect of taxation, it will contract the activity. A regulatory policy that allows legislatures to single out religion in general or specific sects for specific benefits or burdens reduces the size and scope of the religious market. A public subsidy of a particular church will make it harder for other churches to compete. By subsidising one sect, thereby artificially reducing its costs relative to the costs of other sects, a state weakens religious competition. The other sects find it difficult to compete with the established church. Taxing and regulating rival religious institutions may limit their growth.

If a state is committed to freedom of religion, understood as the creation of a free market for religious belief, it should take a neutral stance towards religion. But in order to determine whether religion has been 'aided' (subsidised) or 'penalised' (taxed) by government action, one needs a baseline: 'aid' or 'penalty' as compared with what? 'The treatment meted out by government to nonreligious institutions and activities' is the baseline under the neutrality approach, restated in economic terms. ${ }^{16}$ If government treats competing activities that are secular the same way as it treats religious activities, it will create neither incentives nor disincentives to engage in religious activities, effectively creating a free market of religion.

According to the economic neutrality approach, a state may tax or subsidise religious institutions or activities, but only to the degree that it taxes and subsidises comparable businesses. But it cannot tax or subsidise activities of religion that are so peculiarly religious that there is no private equivalent. So it would be neutral for a state to subsidise the wages of English teachers who work at religious schools if it also subsidises the wages of English teachers at public schools, but it would not be neutral for the state to subsidise the wages of the priests, even if the subsidies are allocated even-handedly among the different faiths. The reason is that individuals must choose between religious and non-religious activity. Even-handed subsidisation of religion poses a threat to freedom of religion because subsidies to religion may induce non-adherents to any religion to decide to join a religious organisation. Neutrality is a means for protecting liberty rather than an end in itself. With neutrality defined in an economic way, when can one justify (1) state subsidies to religious groups and (2) religious exceptions to regulations of general applicability?

\section{May Publicly Funded Subsidies Be Given to Religious Organisations or Religious Activities?}

\subsection{The Economic Neutrality Approach}

From a purely economic standpoint, the case of permitting publicly financed subsidies for religion should turn on whether the likely effect is merely to offset some subsidy for

McConnell and Posner, above n. 5, at 5.

16 Id., at 10-11. 
secular activities. The economic neutrality approach does not require a strict hands-off approach, that is, a policy to exclude religious and religiously affiliated organisations from publicly funded assistance and to deny religion any role in the 'public sphere' ${ }^{17}$ A strict separation between church and state (strict hands-off policy) would have - in some cases - the effect of a tax on religion. The reason is that the religious sector is not isolated from the rest of the economy. Governments have entered more and more fields such as education and care for the less fortunate that previously were private - and usually religious. Religious institutions compete head to head with non-religious ones, for example in providing education, health care and care for the elderly. To exempt religious centres from any program of public subsidies would restrict rather than expand the range of choice available to people concerning religious atmosphere and content; it would amount to a tax on the religious choice and a subsidy for secular alternatives. Religious activities will shrink under a strict hands-off policy. ${ }^{18}$

Denying public funds to religious schools would not be neutral in an economic sense, because it would amount to a tax on religion. Obviously, the fact that public schools would be free to parents, being supported out of taxes, places religious and other private schools at an arbitrary disadvantage, effectively distorting parental free religious choice. Parents would face an economic incentive (created by government policy) to send their children to public schools.

What about religious display on public grounds? Can public display of religious symbols also be seen as offsetting some subsidy for secular activities? It could, although it is less obvious. Suppose that at Christmas time the public grounds display only secular aspects of Christmas, as Santa Claus, and refuse to display a crèche; then religious Christians are denied the same free opportunity to advertise, and enjoy seeing, their version of Christmas. Some people are offended by any religious display. But more people may be offended by banning all religious displays from public property, which they interpret as sending a message of hostility to religion in general or one religion in particular.

Some argue that the state should facilitate religion in general because it helps in teaching and enforcing social and moral norms, which are essential for the functioning of a liberal democracy (which itself is not supposed to formulate or impose such social norms). ${ }^{19}$ In economic terms, religious investments in the teaching and enforcement of moral norms may create external benefits to society (less crime, more promise keeping, etc.). Society can free ride on the religious investments of others. One could view subsidisation of religion as a response to the free rider problem. It is generally accepted in economics that external benefits are under-produced without state intervention, which counts as a market failure. State support of religion (or a particular faith) prevents people from free riding on the religious investments of others, and to that extent, corrects a potential market failure. An efficiency criterion might allow the establishment of religion (or particular faiths) as a cost-justified means to a secular end. For example, if it could be shown that inculcating public school students with the tenets of a particular faith would produce net social benefits, perhaps in the form of a more orderly and productive citizenry, such inculcation would be permitted under an efficiency standard. However, it is not permitted under a standard of neutrality. The requirement of neutrality forbids government to single out religion or a particular religion as an activity to be promoted, however efficient that singling out might be. It would not be neutral to base a grant on the belief that the promotion of religion (or a particular faith) would produce positive results.

\footnotetext{
How is the public sphere distinguished from the private sphere? Government and its activities can be equated with the public sphere. The private sphere consists of those areas in life that government has not wholly regulated.

18 McConnell and Posner, above n. 5, at 8.

19 B. Vermeulen, 'Waarom de vrijheid van godsdienst niet geschrapt mag worden', in H.M.A.E. van Ooijen et al. (eds.), Godsdienstvrijheid: afschaffen of beschermen? (2008) 11, at 12-13.
} 


\subsection{The Case of the Netherlands}

Does the Dutch policy of state aid to religion follow a pattern of economic neutrality? Consistent with the neutrality approach, Dutch religious (affiliated) organisations receive public subsidies for activities in which government intervention is commonplace, such as education, health care and care for the elderly. Article 23 of the Dutch Constitution safeguards freedom of (denominational) education and provides the basis for government funding of private (denominational) education. Hospitals affiliated with a church are eligible to receive government grants on an equal basis with secular hospitals. If the government would only provide public subsidies to competing public organisations or private, secular, organisations, an individual's free religious choice would be heavily distorted.

Contrary to the economic neutrality approach, public authorities do subsidise the construction of church buildings, although the extent to which this happens is much lower than it was in the second half of the $20^{\text {th }}$ century. This is the case where the local governments single out religion for a particular benefit, which is not neutral. From a purely economic standpoint, the case of permitting publicly financed subsidies for religion should turn on whether the likely effect is merely to offset some subsidy for secular activities. Buildings for worship are so peculiarly religious that there is no private equivalent, so that church building subsidies cannot reasonably be seen as an offsetting subsidy. Denying public subsidies for church buildings would not be like taxing religion. Hence the subsidy is a real subsidy. The subsidy may stimulate demand for the established church by reducing the quality-adjusted cost of attending it - suppose, for instance, the subsidy is used to build a magnificent church building. Public authority interferes with private religious choice.

Consistent with the economic neutrality approach, the Dutch government does not pay the salaries of priests and other clergy. The policy of the local authorities of the city of Amsterdam to provide in some cases financial support to religious Islamic organisations in order to promote liberal streams of Islamic faith is a clear violation of the neutrality principle. ${ }^{20} \mathrm{~A}$ government could give financial aid to religious organisations to achieve a public purpose unrelated to religion, but the public purpose cannot include effects (even secular effects) that follow from the adoption or rejection of a religious faith. Thus, it would be neutral to make a grant to an Islamic organisation for various forms of community work if on a secular, objective basis the organisation produces the best results. It would not be neutral to base such a grant on the belief that the promotion of a particular faith would produce positive results. Even if it could be shown that religion (or a particular faith) produces social benefits, perhaps in the form of a more orderly and productive citizenry, it would not be neutral for a state to promote religion for secular ends.

\section{May Religion Be Exempted from Regulations of General Applicability?}

The protection of freedom of religion in the Netherlands may require that an exemption is given on religious grounds from generally applicable laws. The right to freedom of religion implies that governments may not impose a burden on religion, unless it is justified by a compelling governmental purpose, which subsumes the requirement that no means less restrictive of religious freedom would achieve that purpose (proportionality requirement).

\footnotetext{
20 The policy of the city of Amsterdam is outlined in the 'Notitie Scheiding Kerk en Staat' (2008). For example, the city provided support for building the 'Westermoskee' and for subsidising the centre of Islamic culture Marhaba in order to promote liberal streams of Islamic faith.
} 


\subsection{The Economic Framework for Freedom of Religion Cases}

One might think that granting an exemption from regulation to religious people is actually equal to granting an advantage to religion. However, a regulation is not neutral in an economic sense if, whatever its normal scope or its intentions, it arbitrarily imposes greater costs on religious than on comparable non-religious activities. ${ }^{21}$ An exemption that aims at reducing the sacrifice of the believer restores the balance. But when religious observance receives government benefits or protections not needed to counterbalance measures that can be said to interfere with religion, religious observance is promoted, which would be a violation of the neutrality approach.

In claims based on freedom of religion, a plaintiff will usually state that a particular government action violates his right to freedom of religion and will ask for its removal. Judges need to decide whether the government action constitutes a burden on religion. Once a burden on religious exercise has been identified, the question is whether the interest behind the regulation is greater than the burden. McConnell and Posner show how economic analysis can help to solve these questions.

The first issue is whether there is a burden on religion. Not every government action that makes it more difficult to practise religion is a burden on religion. What government action is a burden on religion? McConnell and Posner have suggested an economic test for free exercise violation: substitution effect and disproportionate impact effect. ${ }^{22}$ Under the substitution test, we must compare the choices facing the religious person if there were no such laws. Does it increase the pressure on him to violate the religious norms? There is no substitution effect when the government policy complained of is unrelated to the plaintiff's own conduct - inducing him neither to act nor to refrain from acting. Sometimes, a religious person is spiritually aggrieved with a particular government action, but his conduct is not directly affected. In that case, his claim would fail the substitution test. Under the disproportionate impact test, we must ask the question whether the government action would force religious people to bear a disproportionate share of the burden.

Once a burden on religious exercise has been identified, the question is whether the interest behind the regulation is greater than the burden. Is the government's interest sufficiently compelling to override the freedom of religion claim? The economic test for balancing burdens and benefits is a cost-benefit analysis. The relative strengths of the two interests should not be disregarded. ${ }^{23}$ A stronger governmental interest should be required in order to overcome an onerous burden on religious freedom than in order to overcome a trivial one, and vice versa. So if a particular government action would virtually destroy the ability to practise religion, a very strong government interest is needed to justify such an action. If the injury to the religious interest appears unusually severe (destruction of religion) while the secular interests seem relatively light, the plaintiff should prevail. Moreover, it is important to weigh the marginal impact on religious freedom against the marginal impact on the government's purposes. ${ }^{24}$ When courts would weigh the particular burden on free exercise in the individual case against a powerful but abstract governmental interest, the free exercise claim would appear insignificant.

Some argue that the characteristics of the contemporary market for religions (i.e. pluralistic and containing many novel and idiosyncratic religions) have made the enforcement of the right to freedom of religion unworkable. ${ }^{25}$ What are these problems and how can they be solved? The problem seems to be that with modern religious markets, it has become difficult to assess the credibility of beliefs that a plaintiff seeks to safeguard in a freedom of religion claim. Are people sincere or do they have ulterior motives for their claims? A telling example is that of the 'only and universal church

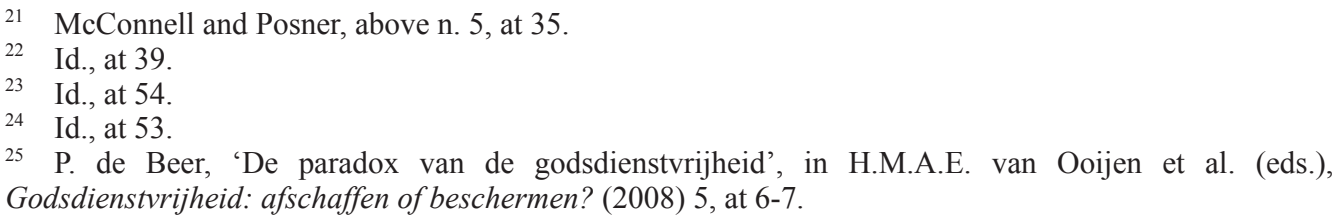


of smokers' in the Netherlands which tries to avoid the legal prohibition to smoke in pubs on the ground of freedom of religion. Believers of this church claim that religious smoking should be allowed. It has also happened that plaintiffs modified their account of their religious views during trial for what might be seen as a tactical advantage. It is inherently difficult for a judge to weigh a non-pecuniary interest of freedom of religion. Is it possible to estimate the value that believers place on religious exercise? How much would the plaintiff be willing to sacrifice to exercise his religion? According to Posner and McConnell, historically validated evidence might help: If we know from history that adherents of a particular faith are willing to undergo great sacrifice rather than foreswear a tenet of their faith, we can use this historically validated shadow price to estimate (very crudely of course) the burden to their current day successors. A novel claim by an individual not affiliated with a traditional denomination carries with it no historical shadow price to lend credence to its strength and sincerity. ${ }^{26}$ Because novel or idiosyncratic religious beliefs do not carry the credibility of beliefs for which persons other than a plaintiff in a freedom of religion case have sacrificed in the past, courts should give greater credence to religious claims advanced by members of long-standing, well-established religious groups. Moreover, free exercise claims are and should be more likely to prevail when they merely reduce the sacrifice required of the believer than when they make the believer better off than nonbelievers. The sacrifice is evidence of the strength and sincerity of the plaintiff's conviction. Finally, free exercise claims should be more likely to succeed if the claimant seeks a benefit of meagre value to nonbelievers, because then there is little risk of ulterior motive.

\subsection{The Case of the Netherlands}

Sometimes, existing Dutch regulations and laws contain explicit exceptions on religious grounds to preserve freedom of religion or of conscience; ${ }^{27}$ in other cases, a judge may declare a particular government action unconstitutional on the basis of the freedom of religion clause (Article 6 Dutch Constitution). The economic framework outlined in Section 4.1 is used to re-examine some of the explicit legal exceptions and court decisions in freedom of religion cases.

The Dutch Equal Treatment Act, containing general rules to provide protection against discrimination on the grounds of religion, belief, political opinion, race, sex, nationality, heterosexual or homosexual orientation or civil status, does not apply to legal relations within religious communities and to the office of minister of religion. ${ }^{28}$ Applying sex discrimination laws to the employer of Roman Catholic clergy conflicts with doctrinal tenets. Regulations particularly disruptive to religious organisations may induce these organisations to alter their conduct or structure and will in any event impose costs on religion disproportionate to those imposed on other regulated activities. Does the government have a compelling interest in enforcing its majoritarian moral principles in the internal organisation of religious communities? Allowing outsiders to suppress religious practices simply on the grounds that they 'offend' is incompatible with any serious notion of freedom of religion. However, the government may have a compelling interest where religious practice would impose costs upon third parties (i.e. in case of negative externalities).

The court of Amsterdam decided that a local authority could not deny welfare benefits to a person who was unavailable for work due to religious grounds. ${ }^{29}$ The city of Diemen denied welfare benefits for a period of 3 months to an unemployed woman. Because she was wearing a burqa, she was refused for two jobs. In addition, she refused to work for

\footnotetext{
26 McConnell and Posner, above n. 5, at 52.

27 Examples of Dutch laws that grant an explicit exemption to preserve freedom of religion or conscious: Art. 18 Wet Aansprakelijkheid Motorvoertuigen (WAM); Doctors and nurses do not have to provide their help for abortion or euthanasia (Art. 20 Wet Afbreking Zwangerschap); No military service is required from people who object to killing people, not even when instructed to do so by the government (Art. 99 Wet Vrijstelling Militaire Dienst).

${ }_{28}$ Article 3 of the Dutch Equal Treatment Act of 2 March 1994 (as amended on 9 September 2004).

29 District Court Amsterdam, 24 May 2007, LJN: BA6917.
} 
a call centre on religious grounds, because it would involve selling lottery tickets. The court decided that she could not be denied welfare payments. Does the outcome of this case fit within the economic framework? The first question is whether the government practice constitutes a burden on religion. Is the denial of welfare benefits equivalent to a burden on the practice of religion or a 'fine' for the woman's obedience to religious principles? According to the substitution test, it is, because it creates a disincentive to follow religious practices. The choice is between being available to sell lottery tickets and receive benefits, on the one hand, and refusing and being denied them, on the other hand. The question of disproportionate impact is more difficult. Welfare benefits are financed by tax contributions made by all citizens, both religious and non-religious. Allowing the woman to receive welfare payments may force other citizens to bear a disproportionate share of the burden of the social security system. Religious exemptions can be given only to the extent necessary to relieve external burdens on religion and not to give believers an advantage over nonbelievers. The disparate impact test may point out an ambiguity in the sense that the government action (alleged to constitute an infringement of the freedom of religion clause) imposes a disproportionate burden on a particular religion, but allowing an exception for a particular religion would disproportionately burden other people. Such cases are the most difficult for courts to solve; it may be up to the legislator to solve the issue. Once a burden on religious exercise is identified, the question becomes whether the interest behind the regulation is greater than the burden. The government obviously has an interest in minimising the number of persons who become dependent for their income on social welfare payments. It can do so by requiring that welfare recipients maximise their efforts to find paid work. But is this government interest sufficiently compelling to justify a burden not to wear clothes that conform to one's religion? The Court in Amsterdam found the burden to be disproportionate. This may be correct. The interest of the government in imposing that burden may not be sufficiently compelling, especially when the government has created many other exceptions to the requirement to maximise efforts to find paid work. One could think of the exemption from the duty to apply for jobs given to single mothers with children below the age of $5 .{ }^{30}$

An Orthodox Jew was found not guilty by the The Hague District Court for failing to produce an identity card (ID) on Sabbath. ${ }^{31}$ The man had faced a fine for failing to prove his identity when requested to do so by the police under the Dutch identification law. Jews are not permitted to carry any objects on Sabbath because it is considered work. The Court decided that an Orthodox Jew on Sabbath cannot be fined for violating the Dutch identification law. Is the Dutch legal obligation to carry ID a burden on religion? It creates a disincentive to follow the religious practice. If the Orthodox person agrees to carry his ID he would not be fined. He therefore faces an economic incentive to violate his religion that he would not have faced if there were no identification law requiring all people to carry ID (substitution effect). Compulsory identification also bears disproportionately on the religious. All people above the age of 14 must carry ID in the Netherlands, but for most the cost of compliance with this rule is trivial. For the Orthodox person, the cost is high. The Orthodox person would probably rather stay at home on Sabbath than go out and carry his ID. The government has an interest in making identification mandatory because it facilitates monitoring and compliance with regulations in the public space. But this competing government interest could be accommodated readily by the police by going to the person's home where proof of identification is available. In fact, in this particular case, the person gave the police the permission to go to his home to pick up his driver's licence, allowing them to get proof of his identity within the hour. Of course, this action causes administrative inconvenience, but the government's interest in reducing administrative inconvenience is not sufficiently compelling to override a freedom of religion claim.

The Court of Appeal of Amsterdam decided that a person could not be punished for importing ayahuasca tea into the Netherlands for religious use in the Santo Daime

\footnotetext{
30 It should, however, be noted that the legal requirements for the temporary exemption for single parents have been made more stringent in 2012 .

31 District Court The Hague, 17 February 2012.
} 
church. ${ }^{32}$ The tea contained DMT (dimethyltryptamine), which is a substance forbidden under the Dutch Opium Law. The court found that the single fact that the import and use of DMT is prohibited under the Dutch Opium Law is not sufficient to override a freedom of religion claim. This is the correct economic result. When courts would weigh the particular burden on free exercise in the individual case against a powerful but abstract governmental interest in public health, the free exercise claim would appear insignificant. Instead, it is important to weigh the marginal impact on religious freedom against the marginal impact on the government's purposes. The marginal impact on public health of the use of DMT in the Santo Daime church is small because the number of participants is low and the use of DMT is controlled, informed and limited. Moreover, even when the public health interest in imposing the burden on religion is compelling, the government should not automatically win. When the burden on religion is onerous (here, the use of DMT is an essential part of religious practice, without which religion could not be practised), a very strong governmental interest should be required. As such a strong governmental interest did not exist, the court was right (from an economic perspective) to let the freedom of religion claim prevail.

Nonetheless, some years earlier, the Dutch Supreme Court came to a different conclusion in a similar case involving the use of DMT on religious grounds. ${ }^{33}$ Still, the difference makes economic sense, because here the plaintiff had declared that the use of DMT was not essential for the exercise of her religion, making the injury to the religious interest relatively light compared with the government interest in protecting public health.

The Dutch government financially supports specialised ministries in institutions such as the armed forces and penal institutions. ${ }^{34}$ Is the government violating the economic neutrality principle in these cases? No. In these cases, the burden on freedom of religion is produced through government control over the necessities of religious practice rather than through legal regulation. For example, for a prisoner to celebrate mass the government must supply the priests and the chapel. The same is true for military stationed in distant countries. In these circumstances, the failure of the government to undertake affirmative steps to make religious exercises possible will be the functional equivalent of absolute coercion: the believer will be forced to substitute away from the religious practice. Where government action has precluded private citizens from maintaining their religious practices without government cooperation, the government cannot then claim that a refusal to cooperate is 'neutral'.

\section{The Role of Religion in Modern Society}

\subsection{Introduction}

In the contemporary public, political and academic debate on the role of religion in Dutch society, one can distinguish two opposing positions: those who argue that religion is, on balance, beneficial to society, contending that the state should increase its support for religion, and those who are skeptical about the value of religion in a modern society, arguing that government authorities should stop cooperating with and providing public funds to religious organisations. ${ }^{35}$ These opposing positions are essentially based on different views about the contribution of religion to people's integration in Dutch society. The former group thinks that there is a positive relationship between religion and integration, whereas the latter considers religion to be an obstacle to integration.

The discussion about the role of religion in society is not a new one. Adam Smith, for example, believed that religion was, on balance, useful in shaping moral values, while

32 Court of Appeal Amsterdam, 24 February 2012, LJN: BV6888.

33 The Dutch Supreme Court, 9 January 2007, LJN: AZ2497.

34 S.C. Van Bijsterveld, 'Religious Liberty and Church Autonomy in The Netherlands', in G. Robbers (ed.), Church Autonomy (2001), at 70.

35 B.C. Labuschagne (ed.), Religie als bron van sociale cohesie in de democratische rechtsstaat? (2004); L. Nickolson, Met Recht Geloven. Religie en maatschappij in wet en debat (2008), at 94; H.M.A.E. van Ooijen et al. (eds.), Godsdienstvrijheid: afschaffen of beschermen? (2008). 
David Hume believed that, on balance, it was destructive for society. ${ }^{36}$ Interestingly, unlike the current calls for less government interference and cooperation with religion made by those who think religion is an obstacle for integration, Hume thought that more regulation and establishment of religion by government were required to curb the destructive forces he associated with religious strife. Hume's reasoning was that in an unregulated market, each religious group will have an incentive to maximise the number of his 'customers' by disregarding 'truth, morals, or decency' and appealing to the 'passions and credulity of the populace'. It was necessary for the state to regulate this competition in order to protect 'the political interest of society'. ${ }^{37}$

Those who currently call for a greater role for religion argue that modern societies may be ripe for a moral revolution that will restore governance by norms to the high place it once occupied and that religion plays a vital role in this process. British Prime Minister Cameron, for example, said in December 2011 that the UK is experiencing a slow-motion moral collapse reflected in England's riots in August 2011 and that religion must help to offer solutions. ${ }^{38}$ Cameron says Christian leaders, and those from other faiths, have a vital role in restoring values of responsibility, hard work, charity and compassion in British society. Is the premise of this argument valid? In the following sections, it is analysed whether religion can contribute much to the enforcement of social and moral norms under the conditions of modernity.

\subsection{Religion as a Social and Moral Norm Producer and Enforcer}

More than 200 years before David Cameron's speech, Adam Smith had already noted that the significance of religion for behaviour is in facilitating governance by social norms. Smith noted that one of the most economically significant functions of religion was to provide strong incentives to follow moral strictures that helped to support civil society, that is, honesty, benevolence, restraint from violence and so forth. In 1776, Adam Smith published The Wealth of Nations. ${ }^{39}$ Smith saw what we see: the progress of modernity, he noted, was not undermining religion in the Great Britain of his day. Instead, religious revivals were blooming. Smith observed a relationship between these revivals and the process what we now call urbanisation. ${ }^{40}$ Young people, arriving in cities in search of work, faced new opportunities and temptations without the structure that village life - with its communities of relatives and others that watched and guided young people - had provided. But the city's small sectarian religious congregations gave rural immigrants a social-support network and a moral code that could keep them on the straight and narrow as they built new lives. These movements were a response to the dislocations of modernity; there was no reason to expect them to fade away. Also in present-day modern cities, we see that people, especially immigrants, join religious organisations for moral and social support.

What are social norms? A social norm is a rule that is neither promulgated by an official source, such as a court or legislature, nor enforced by the threat of legal sanctions, yet is regularly complied with. ${ }^{41}$ Norms are enforced by internalised values, by refusals to interact with the offender (ostracism), by disapproval of his actions and sometimes by private violence. ${ }^{42}$ Why do we have or need social norms $?^{43}$ In economic models in which rational actors take others' actions as given, individuals cannot cooperate for the purpose of creating collective goods. Everyone would cheat on the cooperative project,

36 R.A. Posner, Frontiers of Legal Theory (2001), at 307.

37 For references to David Hume on this point see G.M. Anderson, 'Mr. Smith and the Preachers: The Economics of Religion in the Wealth of Nations', 96 Journal of Political Economy 1066, at 1073 (1988).

38 The four nights of rioting in August 2011 were considered to be the worst rioting in London in decades. Many shops were looted or set on fire.

39 A. Smith, An Inquiry into the Nature and Causes of the Wealth of Nations, edited by R.H. Campbell, A.S. Skinner and W.B. Todd (1776/1976).

40 Smith, above n. 39, at 795 .

41 R.A. Posner and E.B. Rasmusen, 'Creating and Enforcing Norms, with Special Reference to Sanctions',

19 International Review of Law and Economics 369, at 369 (1999).

42 Posner and Rasmusen, above n. 41, at 370.

43 E.A. Posner, Law and Social Norms (2000). 
because each person does better by cheating when others cooperate (he obtains part of the surplus without contributing to it) and each does better by cheating when others cheat (he avoids incurring the costs of contributing to a surplus that would not be created). This is called the prisoner's dilemma or the problem of collective action. Governments can and do solve this problem. Contract law, for example, solves the problem of opportunistic behaviour in non-simultaneous exchange transactions by sanctioning the party who breaches his part of the agreement. Yet, people often engage in cooperative activities, including the production of various standard public goods, in the absence of legal enforcement. Ellickson's study of cattle ranchers and farmers in Shasta County, California, shows that these people do not rely heavily on the law and do not even have a good idea of what the law is, yet they cooperate in impressive ways. Neighbouring landowners repair fences, retrieve stray cattle, pay for damage done by their cattle to the property of others, keep their promises and pay their debts. ${ }^{44}$ One explanation of these phenomena is that 'social norms' deter the undesirable conduct. There are many situations in which everyone benefits from widespread conformity to a particular standard of behaviour, such as honesty or keeping promises. However, situations may arise in which an individual would find it to his advantage to cheat and thus to disobey the norm. Why, then, don't people behave opportunistically whenever they have a chance? Most people are probably more afraid of their mother's disapproval than they are of getting caught by the police. Most people are worried that their colleagues, neighbours and coworkers will laugh at them, or be disgusted by them, whenthey violate local norms. It is the informal sanctions of scolding, shunning, ridicule and the like that actually enforce most good behaviour most of the time.

The governance by social and moral norms critically depends on the existence of coercive mechanisms of non-legal enforcement and costly exit. If people can cheat without consequence, either because no one punishes them or because they can leave cheaply when people threaten to punish them, social and moral norms may not be effective. There is a potential free-rider problem in norm enforcement. Because norm enforcers are unpaid, each will have an incentive to hang back from undertaking costly action, hoping that others will step forward.

Why is it that religious groups are relatively effective in enforcing social and moral norms ${ }^{45}$ They can provide low-cost enforcement services. The concept of a supreme being serves as an enforcement mechanism for moral conduct among believers. The belief in God constitutes a kind of internal moral enforcement mechanism. But there may also be improved external monitoring within religious groups. Religious groups can more readily monitor and micromanage the behaviour of members who misbehave in matters large and small. Adam Smith believed that the more denominations there were, and hence the smaller on average each was, the more effective religion would be in regulating morals, because the free-rider problem would be diminished. ${ }^{46}$ Norms are more likely to be effective the smaller the group that is subject to them is. Repetitive transactions, which are more frequent among members of a small group than among members of a large one, both reduce the cost of ostracism to the ostracisers and make it easier to identify norm breakers. Religious groups have also been effective in enforcing norms by making exit from the group more costly. Modern economic literature on religion emphasises the efforts of religious groups to increase the costs of defection, or exit, by inculcating their members with deviant characteristics of behaviour or appearance. ${ }^{47}$ For example, the non-legal enforcement of social norms in Amish communities is effective because the Amish constitute an isolated subculture from which exit is costly. The Amish do not permit their children to be educated beyond elementary school. This

\footnotetext{
44 R.C. Ellickson, Order Without Law (1991). See also L. Bernstein, 'Opting Out of the Legal System: Extralegal Contractual Relations in the Diamond Industry', 21 Journal of Legal Studies 115 (1992); S. Macaulay, 'Non-Contractual Relations in Business: A Preliminary Study', 28 American Sociological Review 55 (1983); E.A. Posner, 'The Regulation of Groups: The Influence of Legal and Nonlegal Sanctions on Collective Action', 63 University of Chicago Law Review 133 (1996).

45 E.A. Posner, 'The Legal Regulation of Religious Groups', 2 Legal Theory 33 (1996).

46 Smith, above n. 39, at 796.

47 L. Iannoccone, 'Sacrifice and Stigma: Reducing Free-Riding in Cults, Communes, and Other Collectives', 100 Journal of Political Economy 271 (1992).
} 
makes it difficult for Amish to function in the larger culture, but makes the enforcement of social norms more effective ${ }^{48}$ Knowing that non-legal enforcement of social norms is costly (excommunication, ostracism), a person will be less inclined to violate social norms.

\subsection{Religion and the Enforcement of Moral and Social Norms under the Conditions Prevailing in a Modern Society}

Can religion contribute a great deal to the enforcement of moral and social norms under the conditions prevailing in a modern society? This is an open question, but there are, nevertheless, reasons to doubt the realism of suggesting that religion could restore governance by social and moral norms to the high place it once occupied.

Morality may be losing its grip on modern people, according to Posner: 'Increasingly, it seems, we are constrained in our personal behavior by law and reciprocity rather than by social norms'. ${ }^{49}$ Privacy, wealth, urbanisation, occupational and geographical mobility, and education and information, however acquired - all of which have become abundant in modern times - foster individualism. They do so by emancipating people from familial and other small local groups, which undermines the coercive power of norms because norms are more effective when people are under the observation of their peers and cannot easily leave their peer group. Modern privacy law contributes to this tendency because it minimises the non-legal enforcement of social norms by depriving the crowd of the information it needs to inflict sanctions. Although there is no lack of norms today, including new ones such as anti-smoking, the new norms are to a considerable extent optional and the old ones are becoming so; according to Posner: 'Nowadays, you can choose the norms you like by choosing the activity, the occupation, the church and the social set that has a system of norms compatible with your character and preference'. ${ }^{50}$

A person might be enticed into a religious group by features unrelated to its norms and find himself willy-nilly bound by its norms - but one way in which religions compete for new adherents is by relaxing normative constraints; according to Posner: 'With some exceptions, such as Mormonism and ultra-Orthodox Judaism, modern religions in America and other wealthy countries keep up the number of their members by reducing the cost of membership, which they do by minimising the number of hedonistic and other self-interested pursuits forgone'.${ }^{51}$ A monopoly religion can be stern, because it has a captive market. Competitive religions cannot afford to be stern any more than competitive sellers of ordinary goods and services can afford to treat their customers in a censorious manner.

Finally, the strategy utilised by religious groups to make non-legal enforcement of social norms effective by making exit more costly has become increasingly costly. The price that a group pays for cultivating deviant values or manners is very high for its members. ${ }^{52}$ If these values and manners deviate from the values and manners of the larger society, the price paid is the loss of transactional opportunities with individuals and firms of the larger society and a limitation of potential income. ${ }^{53}$ Members of the larger society may be reluctant to trade with individuals who think, act and speak very differently. Rare exceptions exist where a religious group is large enough to achieve economies of scale in trade within the group. A well-known example is that of the

48 Posner (2001), above n. 36, at 298.

49 R.A. Posner, The Problematics of Moral and Legal Theory (1999), at 74. People sometimes respond to allegations of social or moral norm violation by saying that they are not doing anything against the law, supporting the claim that morality has less effect on human behaviour than laws.

50 Posner (1999), above n. 49, at 75.

51 Id., at 75 . As far as it concerns the Netherlands, Orthodox Protestantism is a counterexample of the idea that religions relax their normative constraints in order to be attractive to their members.

52 Posner (2001), above n. 36, at 308.

53 The economic literature sees a trade-off between group identity (distinctiveness and separateness), on the one hand, and social integration (cohesion), on the other hand. See J. Roback, 'Plural but Equal: Group Identity and Voluntary Integration', 8 (2) Social Philosophy and Policy 60 (1991). 
Orthodox Jews who have been able to achieve a commanding position in the international trade in diamonds without recourse to the law to enforce the norms of the trade. But they are only a small fraction of the Jewish population. The astonishing Jewish economic and professional success in the United States goes hand in hand with Jewish integration. ${ }^{54}$

\section{Conclusions}

To a large extent, the Dutch outcomes in religious cases follow a pattern of economic neutrality. The cases in which religious institutions receive public money and those where religion receives an exemption to generally applicable law are usually those where a denial of those benefits would amount to a government 'tax' or 'burden' on religion. If a country, such as the Netherlands, is committed to the value of freedom of religion, understood in economic terms as a free market for religious belief, its government should not tax or burden religion in the sense of creating disincentives to religious choice. Public subsidies to religious organisations and religious exemptions are frequently misunderstood as forms of state promotion of religion. But when looked upon from an economic perspective, they aim, in some cases, at removing governmental disincentives on religious choice, in which case they are justified under an economic neutrality approach.

There are also instances where the (local) Dutch government does not follow the logic of the economic neutrality approach. This is the case for the policy of Dutch local governments to grant benefits to religious organisations based on the belief that the promotion of religion will provide positive results for society. Even if it could be shown that religion (or a particular faith) produces social benefits, perhaps in the form of a more orderly and productive citizenry, it would not be neutral for a state to promote religion for secular ends. Moreover, under the conditions prevailing in a modern society, it is an open question whether religion can contribute a great deal to the enforcement of social and moral norms.

E.I. Wilder and W. Walters, 'Ethnic and Religious Components of the Jewish Income Advantage, 1969 and 1989', 68 Sociological Inquiry 426 (1998). 